\title{
Outcome of pregnancy in patients with systemic lupus erythematosis at Korle-bu Teaching Hospital
}

\author{
Ida Dzifa Dey ${ }^{1,2}$, Jerry Coleman ${ }^{2,3}$, Harriet Kwarko ${ }^{1,2}$ Michael Mate-Kole ${ }^{1,2}$ \\ Ghana Med J 2016; 50(2): 72-77 DOI: http://dx.doi.org/10.4314/gmj.v50i2.4 \\ 'Department of Medicine and Therapeutics, Korle-bu Teaching Hospital, P.O. Box KB 77 Accra, Ghana \\ ${ }^{2}$ School of Medicine and Dentistry, College of Health Sciences, University of Ghana P.O. Box GP 4236, Accra \\ ${ }^{3}$ Department of Obstetrics and Gynaecology, Korle-bu Teaching Hospital, P.O. Box KB 77 Accra, Ghana
}

Corresponding author: Dr Ida Dzifa Dey

E-mail: dzifakay@gmail.com

Conflict of interest: None declared

\begin{abstract}
SUMMARY
Objective: To study maternal and fetal outcomes in Ghanaian women with systemic lupus erythematosus (SLE).

Methods: Retrospective study of pregnancies in women with SLE in a single centre in Ghana.

Results: The mean age was 30.1 years and all were nulliparous. Two out of the seven pregnancies were in disease remission at the time of booking. Nephritis without renal impairment was present in 7 pregnancies (6 women). One woman developed intrapartum eclampsia. Two women had secondary antiphospholipid syndrome (APS). Two suffered early fetal losses and one late fetal loss at 32 weeks. All three who lost their fetus had uncontrolled hypertension. Six had mild flares mainly joint pains during pregnancy. There was no maternal mortality. The median gestational age at delivery was 38 weeks (range, 16 to 40 weeks) and the mean birth weight was $3017 \mathrm{~g}$; the median Apgar scores were 8 and 9 at 1 and 5 minutes of life, respectively. There were no cases of intrauterine growth restriction (IUGR). There were no cases of congenital heart block or neonatal lupus.

Conclusion: Good pregnancy outcomes are possible in women with SLE even in resource poor settings. . All pregnancies should still be considered high risk and be managed jointly between the obstetricians, the perinatologists and the rheumatologists, in particular, those with renal involvement and hypertension. Long term follow up of a larger cohort is needed.
\end{abstract}

Funding: None declared

Keywords: Systemic lupus erythematosus, pregnancy, foetal outcomes, maternal outcomes.

\section{INTRODUCTION}

Systemic Lupus Erythematosus (SLE) is predominantly a disease of women and it tends to affect women during their childbearing years. ${ }^{1}$ Worldwide there is a higher incidence in people of African descent. ${ }^{2}$ Over the years there has been an improvement in the life expectancy and quality of life of patients with SLE due to improvements and new innovations in disease management.

Fertility in SLE patients is generally comparable to the general population, though in the past, patients with SLE were discouraged from getting pregnant by doctors not familiar with the disease and its management with the fear that pregnancy might worsen disease outcome. With careful management and better disease control, maternal and fetal outcomes have improved and pregnancy is no longer contraindicated but is still associated with high risks. ${ }^{2}$
Adverse fetal outcomes such as increase pregnancy loss, intrauterine growth restriction, preterm delivery have also been documented. ${ }^{3}$ For those with renal involvement, successful outcome of pregnancy may be expected even in the more severe forms of lupus nephritis if gestation begins after a persistent clinical remission, usual recommendation being up to six to 12 months of stable disease activity. ${ }^{4}$ Both lupus nephritis and antiphospholipid antibodies increase the risks for maternal hypertension and premature births. ${ }^{5}$ Therefore, the current evidence supports timing of pregnancy relative to SLE activity and multispecialty care of these patients. ${ }^{6}$ SLE is reported to be rare in sub-Saharan Africa ${ }^{7,8}$ and so most physicians and obstetricians may not be familiar with the management of cases, though clinical audits suggest more numbers than expected., ${ }^{910}$ 
Due to the tendency of SLE to affect women in their childbearing year's and the likelihood of more pregnancies occurring in these group of patients, we report on the outcomes of pregnant SLE women who were managed at the Korle Bu Teaching Hospital.

\section{METHODS}

Patients who were diagnosed to have SLE using clinical and laboratory criteria in keeping with American College of Rheumatology (ACR) criteria ${ }^{11}$ and had been pregnant over the preceding year( i.e. between the year 2013-2014) had their data collected retrospectively.

The patients had all been all under the care of the Rheumatologist and the Obstetricians at the Korle bu Teaching Hospital and were subject to usual care and or more frequent reviews as dictated by their conditions. The data were analysed by their demographic characteristics, clinical and serology features and laboratory ab- normalities including the presence of abnormalities of urinary sediment. Treatment during pregnancy, the outcome of the pregnancy and the state of the baby was also documented. Risks of adverse pregnancy outcomes and disease flares were identified.

\section{RESULTS}

A total of seven pregnancies in six SLE patients with a mean age of 30.1 years (age range 27 to 32) were followed up until the end of their pregnancies. Only two were in clinical remission before they got pregnant.

Six of these patients complained of joint pains and on examination had skin lesions during their pregnancy. Three of the patients had elevated blood pressure, which remained raised in spite of treatment with antihypertensive drugs. The highest blood pressure measured was $160 / 100 \mathrm{mmHg}$.

Table 1 Laboratory results

\begin{tabular}{|c|c|c|c|c|c|c|c|}
\hline Lab features & $\begin{array}{l}\text { Patient } \\
\text { RH029 }\end{array}$ & $\begin{array}{l}\text { Patient } \\
\text { RH029 }\end{array}$ & $\begin{array}{l}\text { Patient } \\
\text { C25 }\end{array}$ & $\begin{array}{l}\text { Patient } \\
\text { RH } 227\end{array}$ & $\begin{array}{l}\text { Patient } \\
\text { RH } 084\end{array}$ & $\begin{array}{l}\text { Patient } \\
\mathrm{RH} 483\end{array}$ & $\begin{array}{l}\text { Patient } \\
\mathrm{RH} 486\end{array}$ \\
\hline ANA & $1: 640$ & Positive & Positive & $1: 320$ & $1: 640$ & Negative & $1: 320$ \\
\hline Anti-ds DNA & Positive & + & Positive & $1: 40$ & $1: 80$ & Not done & Negative \\
\hline Anti Sm & Positive & + & Positive & Not done & Not done & Not done & Not done \\
\hline Anti Ro & Negative & Not done & Positive & Not done & Not done & Not done & Not done \\
\hline Anti La & Negative & Not done & Positive & Not done & Not done & Not done & Not done \\
\hline Antiphospholipid syndrome & Positive & Positive & Not done & Not done & Positive & Not done & Negative \\
\hline Complement C3 (83-193) & Not done & 96 & 88 & 97 & 84 & 78 & Not done \\
\hline Complement C4 (15-57) & Not done & 42 & 45 & 27 & Not done & Not done & Not done \\
\hline Urine protein & $3+$ & $1+$ & Not done & $3+$ & $1+$ & $3+$ & Trace \\
\hline Urine red blood cells & Negative & Trace & Not done & $3+$ & $2+$ & $3+$ & Negative \\
\hline Haemoglobin g/dl & 10. & 11.3 & 13.3 & 9.9 & 11.0 & 10.5 & 10.8 \\
\hline WBC & 5.9 & 3.3 & 5.1 & 6.9 & 6.3 & 6.4 & 6.1 \\
\hline Platelets & 347 & 229 & 176 & 386 & 168 & 89 & 71 \\
\hline ESR & 116 & 64 & Not done & 132 & 57 & Not done & Not done \\
\hline Urea $(2.5-7.5 \mathrm{mmol} / 1)$ & 2.1 & 3.7 & 6.9 & 6.6 & 3.7 & 3.6 & 3.2 \\
\hline Creatinine $(40-110 \mathrm{umol} / \mathrm{l})$ & 31 & 62 & 47 & 142 & 83 & 69 & 64 \\
\hline Urine albumin creatinine ratio $(0.0-2.9)$ & Not done & 40.24 & 49.75 & 77.10 & 4.07 & 671.0 & Not done \\
\hline Renal biopsy & Not done & Not done & $\begin{array}{l}\text { Lupus } \\
\text { nephritis } 3 \\
\text { Class III - } \\
\text { Focal lupus } \\
\text { nephritis } \\
\text { (active and } \\
\text { chronic; } \\
\text { prolifera- } \\
\text { tive and } \\
\text { sclerosing) }\end{array}$ & $\begin{array}{l}\text { Patient re- } \\
\text { fused biopsy }\end{array}$ & Not done & $\begin{array}{l}\text { Lupus } \\
\text { nephritis } 4 \\
\text { Class IV - } \\
\text { Diffuse } \\
\text { lupus ne- } \\
\text { phritis } \\
\text { (active and } \\
\text { chronic; } \\
\text { prolifera- } \\
\text { tive and } \\
\text { sclerosing; } \\
\text { segmental } \\
\text { and global) }\end{array}$ & Not done \\
\hline
\end{tabular}




\section{Laboratory results}

Laboratory results are shown in Table 1. Antinuclear antibodies (ANA) were tested in all six of the patients. The titre was elevated in five out of the six patients ranging from 1:320 to $1: 640$ and negative in one patient.

Antibody to double stranded DNA, (Anti ds DNA) was requested in five patients and found to be positive in four. Anti Ro and Anti La antibodies was tested in three patients and found to be positive in one patient.

Complement 3 and Complement 4 components of the complement pathway were tested in three patients and levels were within the normal range but low in one patient. All patients had urine tested for protein. Significant proteinuria was found in three, and also significant numbers of red blood cells (rbcs) found in the urine of two patients during the course of pregnancy. The mean Hemoglobin level was $10.73 \mathrm{~g} / \mathrm{dl}$ (SD 1.41), mean platelet count was 177 x $109 / 1($ SD 109.79), and mean White cell count was $4.98 \times 109 / 1($ SD1.06).

The Urine albumin:creatinine ratio was found to be significantly raised in three patients. Urea and creatinine levels was found to be normal in all patients Two patients of the three had previous renal biopsies which showed Class III - Focal lupus nephritis (active and chronic; proliferative and sclerosing), and Class IV Diffuse lupus nephritis (active and chronic; proliferative and sclerosing; segmental and global) lupus nephritis. One completed treatment with cyclophosphamide four years earlier and was in remission and one was scheduled for treatment when she got pregnant.

Table 2 Treatment results

\begin{tabular}{|c|c|c|c|c|c|c|c|c|}
\hline $\begin{array}{l}\text { Clinical } \\
\text { Criteria }\end{array}$ & $\begin{array}{l}\text { Patient } \\
\text { RH029 }\end{array}$ & $\begin{array}{l}\text { Patient } \\
\text { RH029 }\end{array}$ & $\begin{array}{l}\text { Patient } \\
\text { C25 }\end{array}$ & & $\begin{array}{l}\text { Patient } \\
\text { RH } 227\end{array}$ & $\begin{array}{l}\text { Patient } \\
\text { RH084 }\end{array}$ & $\begin{array}{l}\text { Patient } \\
\text { RH } 483\end{array}$ & $\begin{array}{l}\text { Patient } \\
\text { RH486 }\end{array}$ \\
\hline Age & 27 & 28 & & 29 & 36 & 29 & 31 & 31 \\
\hline $\begin{array}{l}\text { Active Lupus fea- } \\
\text { tures }\end{array}$ & $\begin{array}{l}\text { Joint pain, } \\
\text { Rash }\end{array}$ & $\begin{array}{l}\text { Joint pain, } \\
\text { rash }\end{array}$ & $\begin{array}{l}\text { Joint pain, } \\
\text { nephritis }\end{array}$ & & $\begin{array}{l}\text { Joint } \\
\text { rash }\end{array}$ & Joint pain & Joint pain & $\begin{array}{l}\text { Joint } \\
\text { rash }\end{array}$ \\
\hline Prednisolone & $10 \mathrm{mg}$ & $20 \mathrm{mg}$ & $15 \mathrm{mg}$ & & $10 \mathrm{mg}$ & $10 \mathrm{mg}$ & $\begin{array}{l}\text { 10mg+ } \\
\text { Pulse } \\
\text { Methylpred- } \\
\text { nisolone 1g } \\
\text { for three } \\
\text { days }\end{array}$ & $60 \mathrm{mg}$ \\
\hline Hydroxychloroquine & $200 \mathrm{mg}$ & $200 \mathrm{mg}$ & Nil & & $400 \mathrm{mg}$ & $200 \mathrm{mg}$ & $200 \mathrm{mg}$ & Nil \\
\hline Azathioprine & Nil & Nil & $75 \mathrm{mg}$ & & Nil & $75 \mathrm{mg}$ & Nil & Nil \\
\hline Sol Aspirin & $75 \mathrm{mg}$ & $75 \mathrm{mg}$ & Nil & & $75 \mathrm{mg}$ & $75 \mathrm{mg}$ & $75 \mathrm{mg}$ & Nil \\
\hline Nifedipine & $40 \mathrm{mg}$ bd & Nil & Nil & & Nil & Nil & Nil & 30mg dly \\
\hline Amlodipine & Nil & Nil & Nil & & Nil & $5 \mathrm{mg}$ & Nil & Nil \\
\hline Methyldopa & $500 \mathrm{mg}$ bd & Nil & Nil & & Nil & $500 \mathrm{mg}$ bd & Nil & Nil \\
\hline Folic Acid & $5 \mathrm{mg}$ & $5 \mathrm{mg}$ & $5 \mathrm{mg}$ & & $5 \mathrm{mg}$ & $5 \mathrm{mg}$ & $5 \mathrm{mg}$ & $5 \mathrm{mg}$ \\
\hline BP at delivery & $160 / 100$ & $100 / 60$ & $98 / 70$ & & $130 / 70$ & $150 / 105$ & $150 / 100$ & $120 / 80$ \\
\hline $\begin{array}{l}\text { Pregnancy outcome } \\
\text { in weeks }\end{array}$ & $\begin{array}{l}\text { Lost at } \\
32 / 40\end{array}$ & $\begin{array}{l}\text { Delivered at } \\
\text { term }\end{array}$ & $\begin{array}{l}\text { Delivered } \\
\text { term }\end{array}$ & at & $\begin{array}{l}\text { Delivered at } \\
\text { term }\end{array}$ & Lost at $16 / 40$ & Lost at $24 / 40$ & $\begin{array}{l}\text { Delivered } \\
\text { term }\end{array}$ \\
\hline
\end{tabular}

\section{Treatment}

All patients were on immunosuppressive treatments during their pregnancy with prednisolone doses ranging from 10 - 60mg daily. One patient received pulsed Methylprednisolone three months prior to conception as part of the protocol for lupus nephritis and one after delivery for complications. Other treatments included Hydroxychloroquine, Azathioprine and Soluble Aspirin.

Antihypertensive treatment used for those with high blood pressure (BP) was Nifedipine, Methyldopa, and one patient received Amlodipine briefly; this was switched to Methyldopa on confirmation of pregnancy.

\section{Outcome of pregnancy}

Four patients delivered normal healthy babies including one mother who had Anti Ro and Anti La antibodies.

Three pregnancies were lost at various stages of pregnancy namely at weeks 32, 16 and 24 . Two of these patients who lost their babies had significant proteinuria, but all three who lost their babies had high BPs varying from 150/100 - 160/100.

\section{DISCUSSION}

The first rheumatology clinic at the Korle bu Teaching Hospital (KBTH) the premier teaching hospital in Ghana was started in August 2010. 


\section{Original Article}

An audit of patients over a year from June 2011 to June 2012 showed 226 newly diagnosed patients (excluding follow ups) were seen in the clinic, with Rheumatoid arthritis and SLE comprising majority of cases, i.e. $89(39.3 \%)$ and $48(21.2 \%)$ respectively.

This study consisted of only seven pregnancies in six patients with SLE. Though small it gives an encouraging prospect for successful pregnancies in this group of patients who many doctors in Ghana have not had the experience to manage and may not know what to expect in this environment. It also provides preliminary data for future follow up.

Most of the pregnancies were not planned with their doctors, underscoring the difficulty in delaying pregnancy in this group of patients in their reproductive ages who have the need to have children despite the difficulties that it entails vis a vis their condition especially in the face of societal expectations to have children.

Most of the patients had clinical and laboratory evidence of active disease and ideally should not have been the right time for conception. Most studies and recommendations in pregnancy in SLE recommend at least 6 months of stable disease before pregnancy is planned to ensure good outcome for both the mother and fetus regarding disease activity and the chance of a successful pregnancy with minimal complications. ${ }^{12,13}$

It is recommended that prenatal care be initiated at an institution where the obstetrician is experienced in the possible complications of lupus and where consultation with a rheumatologist is available. ${ }^{14}$ This was not the case in this entire group, though they thereafter had regular close follow up by the rheumatologist and obstetrician and in some cases the nephrologists after conception.

A major predictor of outcome of pregnancy in this study appears to be the level of the blood pressure. All patients who lost their pregnancy had high blood pressure both at conception and throughout the pregnancy this was not well controlled according to recommended targets. This correlates with the finding in other studies where the major determinants of a negative outcome have been high blood pressure, nephritis and the antiphospholipid syndrome. Hypertensive complications in lupus increase the risk for preterm birth, intrauterine growth retardation (IUGR) and fetal loss. ${ }^{15,16}$

Preeclampsia and eclampsia can mimic lupus with both presenting with edema, thrombocytopenia, hyperuricemia, anemia, hypertension, proteinuria, renal impairment, and hematuria and additionally seizures in ec- lampsia. The difficulty in distinguishing this was evident in one case who lost the fetus at 24 weeks, with signs and laboratory features suggestive of preeclampsia, but also had features of active SLE with low complements and the rare eye complication of macular detachment that improved with pulsing of methylprednisolone.

The challenge to confidently differentiate if the patient is demonstrating a normal pregnancy sign, a hypertensive complication associated with the pregnancy or a lupus flare was seen in this case and this was complicated with the difficulty of getting fast, accurate results in a limited resource setting. In these circumstances, the inclination is to over treat to safeguard the safety of the mother and fetus and have a successful pregnancy outcome. ${ }^{16}$ The patient had treatment for both SLE flare and had a hysterotomy on account of preeclampsia.

There was evidence of renal involvement in four out of the six patients, but only three were able to do their urine albumin ratios to quantify the protein levels. Ideally the antiphospholipid assay should be tested in all patents especially for those who have lost previous pregnancies as well as the anti Ro and Anti-La antibodies pre-conceptually to determine the risks associated with having these antibodies. Monitoring should include baseline and monthly laboratory tests, serial ultrasonography, fetal surveillance tests, and fetal m-mode echocardiography for mothers with SS-A (Ro) or SS-B (La) antibodies. ${ }^{17}$ These were not available to our patients. One limitation of the study is that the high cost of tests limited our ability to run all tests on all patients.

Treatments used for these patients included low dose prednisolone and in the case of one patient who had a severe flare IV methylprednisolone, hydroxychloroquine and azathioprine. In the absence of any signs or symptoms of active SLE, patients need no definite treatment during pregnancy. ${ }^{16}$ If hydroxychloroquine was in use before conception, it should be maintained throughout pregnancy. If a woman with SLE has antiphospholipid antibodies, prophylactic treatment with aspirin and/or low-molecular weight heparin is indicated to prevent fetal loss. Two of the patients followed up here tested positive for antiphospholipid antibodies.. One patient who tested positive for antiphospholipid antibodies lost the pregnancy despite taking aspirin. Lupus flares during pregnancy were generally treated with hydroxychloroquine, low-dose prednisone, pulse intravenous methylprednisolone, and azathioprine. ${ }^{17}$

All four babies delivered had normal APGAR scores and no birth deformities were recorded. There was no case of neonatal lupus noted, nor intrauterine growth 
restriction. All babies were well in the first three months of monitoring.

There were four caesarian sections and three spontaneous vaginal deliveries (SVD) with no adverse outcome to mothers, but two deliveries by SVD died and one by caesarian section. Mothers remain stable and had neither complications nor SLE flares in the first three months after delivery. Of the mothers who lost their pregnancies two remained stable, one developed acute renal failure and macula detachment with visual impairment. These all normalized during the first three months of monitoring and treatment with pulse intravenous steroids and mycophenolate mofetil. This is reassuring considering the resource limitations.

Pre-pregnancy counselling and multidisciplinary management with other specialists such as the obstetricians and the perinatologists is crucial in improving the maternal and fetal outcome in lupus pregnancies, though such specialists are in short supply in a resource poor environment like Ghana.

\section{Conclusion and future}

These cases provide good evidence that pregnancy is possible in patients with SLE, even in resource poor settings though the numbers are small to make a definite conclusion on outcomes. There is the need to emphasize getting the condition in remission before conception and good control of blood pressure, which are associated with poor outcome.

There is the need to train more health personnel to care for these complicated conditions. These case series would set in motion the collection of long-term data on pregnancy in lupus patients in Ghana to help understand the unique characteristics of patients in Ghana and subSaharan Africa and may open the window to a greater understanding of the pathophysiology of these diseases. There are no conflict of interest reported by authors and no ethical approval was required.

\section{REFERENCES}

1. Flower C, Hennis AJ, Hambleton IR, Nicholson GD, Liang MH. Systemic lupus erythematosus in an African Caribbean population: incidence, clinical manifestations, and survival in the Barbados National Lupus Registry. Arthritis Care Res 2012 Aug;64(8):1151-8. PubMed PMID: 22392730. Epub 2012/03/07. eng.

2. Cortes-Hernandez J, Ordi-Ros J, Paredes F, Casellas M, Castillo F, Vilardell-Tarres M. Clinical predictors of fetal and maternal outcome in systemic lupus erythematosus: a prospective study of 103 pregnancies. Rheumatology (Oxford). 2002
Jun;41(6):643-50. PubMed PMID: 12048290. Epub 2002/06/06. eng.

3. Fine LG, Barnett EV, Danovitch GM, Nissenson AR, Conolly ME, Lieb SM, et al. Systemic Lupus Erythematosus in Pregnancy. Ann Intern Med. 1981;94(5):667-77.

4. Jungers P, Dougados M, Pélissier C, et al. Lupus nephropathy and pregnancy: Report of 104 cases in 36 patients. Archives of Internal Medicine. 1982;142(4):771-6.

5. Smyth A, Oliveira GH, Lahr BD, Bailey KR, Norby SM, Garovic VD. A systematic review and meta-analysis of pregnancy outcomes in patients with systemic lupus erythematosus and lupus nephritis. Clin J Am Soc Nephrol. 2010 Nov;5(11):2060-8. PubMed PMID: 20688887. Pubmed Central PMCID: PMC3001786. Epub 2010/08/07. eng.

6. Al Arfaj AS, Khalil N. Pregnancy outcome in 396 pregnancies in patients with SLE in Saudi Arabia. Lupus 2010 Dec;19(14):1665-73. PubMed PMID: 20947541. Epub 2010/10/16. eng.

7. Westlake S, Edwards C. Anti-malarials and Lupus in West Africa use and lupus in Africans. Lupus 2009 March 1, 2009;18(3):193-5.

8. Zomalheto Z, Assogba M, Agbodande A, Atadokpede F, Gounongbe M, Avimadje M. [Pattern of systemic lupus erythematosus in Benin and West African patients]. Tunis Med. 2014 Dec;92(12):707-10. PubMed PMID: 25879593. Epub 2015/04/17. fre.

9. Adelowo OO, Oguntona SA. Pattern of systemic lupus erythematosus among Nigerians. Clin Rheumatol. 2009 Jun;28(6):699-703. PubMed PMID: 19242770. Epub 2009/02/27. eng.

10. Dey D, Atiase Y, Ernest Yorke E, Ganu V and Mate-Kole C.C . Rheumatology in Ghana - A Paradigm Change: . in Margaret Lartey, Timothy Archampong and Michael O Mate-Kole, editors; Internal Medicine Practice in Ghana: Challenges, Innovations and Future Directions University of Ghana Readers 2015 (Digibooks Ghana Ltd 2015):, pp 7-21.

11. Hochberg MC. Updating the American College of Rheumatology revised criteria for the classification of systemic lupus erythematosus. Arthritis Rheum 1997 Sep;40(9):1725. PubMed PMID: 9324032. Epub 1997/10/27. eng.

12. Carmona F, Font J, Cervera R, Munoz F, Cararach $\mathrm{V}$, Balasch J. Obstetrical outcome of pregnancy in patients with systemic Lupus erythematosus. A study of 60 cases. Eur J Obstet Gynecol Reprod Biol. 1999 Apr;83(2):137-42. PubMed PMID: 10391522. Epub 1999/07/03. eng. 
13. Iozza I, Cianci S, Di Natale A, Garofalo G, Giacobbe AM, Giorgio E, et al. Update on systemic lupus erythematosus pregnancy. Journal of Prenatal Medicine. 2010 Oct-Dec;4(4):67-73. PubMed PMID: PMC3279186.

14. Tan LK, Tan HK, Lee CT, Tan AS. Outcome of pregnancy in Asian women with systemic lupus erythematosus: experience of a single perinatal centre in Singapore. Ann Acad Med Singapore. 2002 May;31(3):290-5. PubMed PMID: 12061288. Epub 2002/06/14. eng.

15. Rahman P, Gladman DD, Urowitz MB. Clinical predictors of fetal outcome in systemic lupus erythematosus. J Rheumatol. 1998 Aug;25(8):152630. PubMed PMID: 9712095. Epub 1998/08/26. eng.

16. Dhar JP, Sokol RJ. Lupus and pregnancy: complex yet manageable. Clin Med Res. 2006 Dec;4(4):31021. PubMed PMID: 17210979. Pubmed Central PMCID: PMC1764808. Epub 2007/01/11. eng

17. Baer AN, Witter FR, Petri M. Lupus and pregnancy. Obstet Gynecol Surv. 2011 Oct;66(10):639-53. PubMed PMID: 22112525. Epub 2011/11/25. eng 